Original communication

\title{
Deaths resulting from the use of firearms by police against motor vehicles: Study of cases in Porto, Portugal
}

\author{
Ezequiel Rodrigues ${ }^{a, *}$, Paula Faria ${ }^{b}$, Agostinho Santos c, a, d, e, Sílvia Fraga ${ }^{f}$ \\ ${ }^{a}$ Faculty of Medicine of Porto University, Department of Legal Medicine and Forensic Sciences, Alameda Professor Hernâni Monteiro, 4200-319, Porto, \\ Portugal \\ ${ }^{\mathrm{b}}$ Faculty of Law of Catholic University of Portugal, Rua Diogo Botelho, 1327, 4160-005, Porto, Portugal \\ ${ }^{\mathrm{c}}$ National Institute of Legal Medicine and Forensic Sciences, Department of Pathology - North Branch, Jardim Carrilho Videira, 4050-167, Porto, Portugal \\ d School of Health Sciences of Minho University, Campus Gualtar, 4710-057, Braga, Portugal \\ e Center of Forensic Sciences, National Institute of Legal Medicine and Forensic Sciences, Largo da Sé Nova, 3000-213, Coimbra, Portugal \\ ${ }^{\mathrm{f}}$ EPIUnit - Institute of Public Health, University of Porto, Rua das Taipas, 135, 4050-600, Porto, Portugal
}

\section{A R T I C L E I N F O}

\section{Article history:}

Received 8 October 2015

Received in revised form

21 December 2015

Accepted 4 January 2016

Available online 12 January 2016

\section{Keywords:}

Forensic medicine

Legal medicine

Deaths

Ballistics

Police shootings

Motor vehicles arrest

\begin{abstract}
A B S T R A C T
The objective of this study was to investigate the terminal ballistics of police shootings in which the bullets went through any motor vehicle structure before fatally wounding the occupants. 6 cases that occurred in Porto district between 1998 and 2013 were studied. The firearms used were $7.65 \mathrm{~mm}(\mathrm{n}=1)$ or $9 \mathrm{~mm}(\mathrm{n}=3)$ calibre semi-automatic pistols and $9 \mathrm{~mm}$ calibre submachine guns $(\mathrm{n}=2)$; the bullets were full metal jacket type. The metal jacket of the collected projectiles was totally or partially destroyed in 3 cases. It exhibited a deformed structure in all cases. The trajectories of the bullets in the vehicles were always more or less linear, even when initial impact was at an oblique angle. The entry holes in the victims' bodies were larger or much larger in size than the calibre of the bullets. They were located, with the exception of one of the cases, in the left half of the body. The trajectories in the victims' bodies were from front to back, in one case, and from back to front in all others. Exit wounds were only found in two cases. Death occurred immediately after the victim was shot only in one case, despite a vital structure has been hit in all cases. The cases studied support the idea that the use of firearms against vehicles with the sole intention of immobilisation entails uncontrollable danger to the lives of the occupants, and especially when done by police forces not specifically trained for that purpose. Therefore, such use of firearms should be avoided.
\end{abstract}

() 2016 Elsevier Ltd and Faculty of Forensic and Legal Medicine. All rights reserved.

\section{Introduction}

The shooting of firearms against motor vehicles, in particular against the tyres, continues to be used by police officers as a means of immobilising motor vehicles in which citizens are fleeing. ${ }^{1-5}$ The use of firearms in this way, besides having reduced effectiveness in the immobilization of vehicles, is also quite inaccurate ${ }^{5}$ because the shots are usually made when the motor vehicles are mobile, and when bullets strike the structure of a motor vehicle they may suffer deformation, fragmentation ${ }^{6}$ and unpredictable trajectory changes. $^{7,8}$

\footnotetext{
* Corresponding author. Jardim Carrilho Videira, 4050-167, Porto, Portugal. Tel.: +351 222073850; fax: +351 222083978 .

E-mail addresses: ezrodrigues@gmail.com,_pdcf09006@med.up.pt (E. Rodrigues).
}

The lack of accuracy when shooting against motor vehicles means that the occupants may sometimes be hit, fatally in some cases, ${ }^{4}$ often in situations where it would only be permissible to shoot to immobilize the vehicles. ${ }^{3,5}$ The high probability of such occurrences has led to recommendations ${ }^{9}$ or even the banning ${ }^{5}$ of the use of firearms against vehicles when the occupants are not acting in a manner that endangers the life or essential physical integrity of police officers or third parties.

When bullets strike motor vehicle structures, their behaviour will be influenced by a number of factors including their velocity, energy and construction (mass, shape and material properties), as well as the angle of incidence ${ }^{10}$ and material they pass through (metal or glass). The terminal wound ballistics performance in the body of the occupants of the vehicles will essentially depend on the bullet's characteristics, ${ }^{11,12,8}$ the effects arising from the interaction with the vehicle's structure, ${ }^{8}$ the occurrence of fragmentation and/ or deformation of the bullets, ${ }^{11}$ the amount of kinetic energy and 
momentum ${ }^{12}$ with which the bullets strike human tissue, ${ }^{11,13}$ the nature of the affected tissues ${ }^{14,15}$ and the anatomical area and anatomical structures that are impacted. ${ }^{15}$

The most common bullet associated with police shootings is the $9 \mathrm{~mm}$ Luger full metal jacket (FMJ) round nose. This bullet shows the smallest deformation ${ }^{16}$ regardless the separation of the core and the jacket and even the fragmentation. ${ }^{7}$ At the same time, this bullet presents a considerable capacity of perforation of metal plate and glass, not only at $90^{\circ}$ but also at lesser angles. ${ }^{7}$ The remaining velocity of this bullet after perforate this kind of intermediate targets is high, in some cases $95 \%$ of the maximum. ${ }^{7}$ Because of this remaining velocity, in case of shooting against motor vehicles, it may occur collateral damages, namely when shooting against glasses. ${ }^{8}$ The expandable bullets have been studied as an alternative to the FMJ bullets. ${ }^{17,8}$ However, this alternative is not yet consolidated because, in cases of shooting against a glass window, the expandable bullets still not being effective against an hostile target and not accurate, in particular for shooting lesser than $90^{\circ} .8$

The study of the fatal injuries to the occupants of vehicles that police officers shoot at is deemed relevant to the forensic sciences, in particular, not only for the intrinsic seriousness of such injuries but also due to the shortage of studies that use actual cases in a holistic perspective of the vehicles and the occupants. Such a study may contribute to the discovery of the truth in similar cases where the conduct of the police officers involved is being investigated.

The objective of this study was to investigate the terminal ballistics of fatal police shootings in which the bullets hit the motor vehicle structure before wounding the occupants.

\section{Materials and methods}

A list was requested from the Procuradoria-Geral da República and the Inspeção-Geral da Administração Interna of the criminal proceedings against police officers accused of having caused the death of citizens as a result of discharging their firearms while on duty in Porto district. Between 1998 and 2013, 11 criminal cases involving police officers were identified in the courts. Seven of those cases involved the victims being shot while inside their motor vehicles.

A specific authorisation was also requested from the magistrates in charge of the cases to view the case documents and to digitally reproduce the images of the injuries and the damage to the motor vehicle resulting from the shooting. The study found one case in which the victim was struck at very close range and not through the vehicles structure. As a result, this case was excluded from the study. Thus, the current study will focus on 6 criminal cases.

Information based on the police and court registries and also on the forensic pathology provided by the Instituto Nacional de Medicina Legal e Ciências Forenses, Instituto Público (INMLCF, I.P.) was gathered. A guide was designed for data extraction and the three main topics were addressed: (1) police shooting characteristics (year, time of occurrence, type of incident, position of the victim in the vehicle, position of the victim relative to the officer, type of firearm, make of firearm, calibre of firearm, type of bullet, make of ammunition; calibre of bullet; circumstances surrounding bullet strike to the motor vehicle in terms of its movement; direction of movement of the officer at moment shot fired; judicial decision); (2) forensic ballistics data regarding the vehicle (distance of the shots, no. of shots, initial impact area, angle of incidence, direction of shot(s) that hit the victim, exit area of bullet(s), loss of bullet jacket(s), deformation of bullet(s), significant loss of bullet(s) mass); (3) data related to the forensic medical autopsy (number of bullets that struck the victim; anatomical region of entry wound(s); shape of entry wound(s), dimension(s) of entry wound(s), anatomical region of exit wound(s), shape of exit wound(s), dimension(s) of exit wound, path of the bullet/s through the victim's body, need for medical assistance/hospitalisation, survival time).

Photographs were also collected from forensic ballistics and forensic pathology reports of each of the cases, illustrating the effects of bullets on the structure of motor vehicles and the injuries caused by the bullets in the victims' bodies.

Each case will be specifically described and then a summary of main results will be provided.

\section{Results}

\subsection{Police shooting characteristics}

Table 1 provides a general description of the shots fired. The fact that a submachine gun was only used in cases 2 and 3 is highlighted. In case 1 the calibre of the weapon used was not $9 \mathrm{~mm}$ but $7.65 \mathrm{~mm}$. All the bullets fired were of full metal jacket type (FMJ).

The shots were fired at a time when the motor vehicles struck were mobile, except for case 4 , where the vehicle was stopped. The police officer fired from a moving police car only in case 3 . In the other cases, the police officers fired when they were outside of the police car and in a stationary position.

It was proven at each trial that the intention of the police officers who carried out the shootings was never to hit the occupants but immobilise the vehicles and arrest the fugitives. The death of the victims was, therefore, considered an accidental event in all cases by the courts. Except for case 6 , the police officers allegedly tried to aim at the tyres of the motor vehicles, but never managed to hit them. The police officers were acquitted in case 1 and 6, and convicted of homicide and sentenced in the other cases.

\subsection{Forensic ballistics and pathology findings: case description}

The bullets that struck the victims were all deformed but had no significant loss of mass. Fig. 1 provides an example related to case 1 . With the exception of cases 1 and 6, the bullets metal jacket had totally or partially separated from its internal core. The bullets ended their travel in the body of the victims (number of bullets $=5$ ) or inside the vehicle (number of bullets $=3$ ).

Table 2 and Table 3 summarise other data contained in the forensic ballistics and forensic pathology reports. The relevant specificities of each case are presented in detail below.

\subsubsection{Case 1}

The bullet was fired through the window of the left front driver's door of the vehicle and struck the driver in the posterior of the left hemithorax (Fig. 2), passing through the eighth intercostal space on the left side and fracturing the upper edge of the ninth rib. The bullet then travelled in the chest cavity to the left diaphragmatic angle and entered the left lung. It then continued to the abdomen, where it injured the stomach, intestines, and upper and lower zones of the right lobe of the liver. It was not possible to obtain information about the anatomical region in which the bullet was found. The victim underwent numerous surgeries in a hospital environment, before dying $8 \mathrm{~h}$ after being shot.

\subsubsection{Case 2}

The police officer fired 6 rounds in the direction of the back of a light commercial motor vehicle. Two of the bullets with a horizontal trajectory from back to front, perforated the left rear door of the motor vehicle and crossed the metallic cargo compartment (Fig. 3) and the driver's seat in a rectilinear path, striking the victim in the right half of the lumbar region (Fig. 4). In the spine, the bullets fractured the plate, pedicle and transverse apophysis of 
Table 1

Police shooting characteristics, Porto (1998-2013).

\begin{tabular}{|c|c|c|c|c|c|c|}
\hline & Case 1 & Case 2 & Case 3 & Case 4 & Case 5 & Case 6 \\
\hline Year & 1998 & 1998 & 2006 & 2008 & 2012 & 2013 \\
\hline Position of the police officer & $\begin{array}{l}\text { Outside of the police } \\
\text { motor vehicle }\end{array}$ & $\begin{array}{l}\text { Outside of the police } \\
\text { motor vehicle }\end{array}$ & $\begin{array}{l}\text { Inside of the police } \\
\text { motor vehicle }\end{array}$ & $\begin{array}{l}\text { Outside of the police } \\
\text { motor vehicle }\end{array}$ & $\begin{array}{l}\text { Outside of the police } \\
\text { motor vehicle }\end{array}$ & $\begin{array}{l}\text { Outside of the police } \\
\text { motor vehicle }\end{array}$ \\
\hline $\begin{array}{l}\text { Seat occupied by the victim } \\
\text { in the vehicle }\end{array}$ & Driver's seat & Driver's seat & Rear seats & Driver's seat & Rear seats & Driver's seat \\
\hline $\begin{array}{l}\text { Position of victim in relation } \\
\text { to the police officer }\end{array}$ & Side on & Back to & Back to & Facing & Back to & Side on \\
\hline Type of firearm & Semi-automatic pistol & Submachine gun & Submachine gun & Semi-automatic pistol & Semi-automatic pistol & Semi-automatic pistol \\
\hline Make of firearm & FN 140 DA & Beretta12S & FAMAE SAF & Glöck19 & Glöck19 & Glöck19 \\
\hline Calibre of firearm & $7.65 \mathrm{~mm}$ & $9 \mathrm{~mm}$ & $9 \mathrm{~mm}$ & $9 \mathrm{~mm}$ & $9 \mathrm{~mm}$ & $9 \mathrm{~mm}$ \\
\hline Type of bullet & FMJ & FMJ & FMJ & FMJ & FMJ & FMJ \\
\hline Make of ammunition & Fiocchi & INDEP & INDEP & INDEP & Sellier\& Bellott & Sellier\& Bellott \\
\hline Calibre of bullet & $7.65 \times 17 \mathrm{~mm}$ & $9 \times 19 \mathrm{~mm}$ & $9 \times 19 \mathrm{~mm}$ & $9 \times 19 \mathrm{~mm}$ & $9 \times 19 \mathrm{~mm}$ & $9 \times 19 \mathrm{~mm}$ \\
\hline Bullet weight (grains/grams) & $73 / 4.73$ & $115 / 7.45$ & $115 / 7.45$ & $115 / 7.45$ & $115 / 7.45$ & $115 / 7.45$ \\
\hline Bullet shape & Round nose & Round nose & Round nose & Round nose & Round nose & Round nose \\
\hline
\end{tabular}

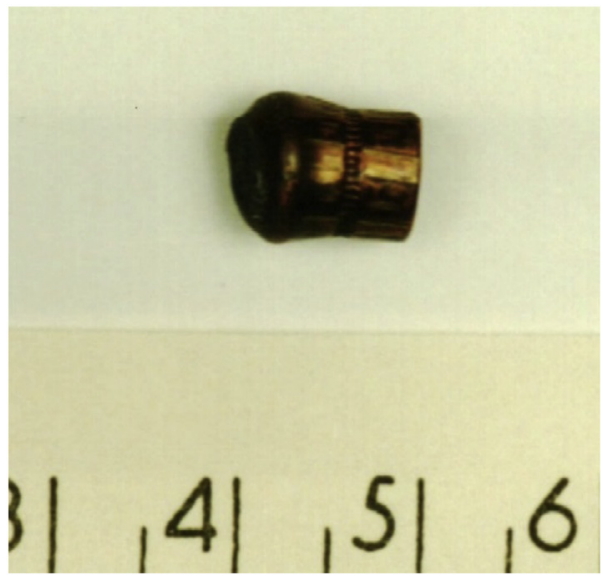

Fig. 1. Case 1: Close up of the flattening of bullet ogive.

lumbar vertebra one (L1), with intracanal fragments. The fragments penetrated into the abdominal cavity, causing hemoperitoneum, perforation of the fourth part of the duodenum (D4), wound to the root of the mesentery, perforation of two loops of the jejunum, a wound and perforation of the meso of the last ileal loop, laceration of the transverse mesocolon and abrasion of the transverse colon, retroperitoneal haematoma from the root of the mesentery to the paracolic gutter and cephalo-pancreatic region. One of the bullets was found in the anterior wall of the abdomen and the other in the root of the mesentery. The victim's death occurred $294 \mathrm{~h}$ after the shooting and was due to septic intra-abdominal complications and heightened hemodynamic instability with signs of renal and haemapathologic dysfunction arising from the described injuries.

\subsubsection{Case 3}

The police officer fired and 5 bullets struck the motor vehicle. Two of these bullets went through the boot door, in a trajectory from the back of the vehicle to the front. The bullets continued through the right side of the back seat and then hit the passenger. The entry wounds were on the left hemithorax of the victim. One of the bullets, on a trajectory from back to front (Fig. 5), destroyed the left side plates of the fifth dorsal vertebra without destroying the vertebral body. It then pierced the parietal pleura, at the same level, the posterior and anterior sides of the left pleural cavity, entering and exiting the upper lobe of the left lung and lacerating the upper part of the aortic arch. It then passed close to the articulation of the second left rib with the sternum, creating an elliptical-shaped exit wound with contusion around the edge (Fig. 6) and causing bone splinters to be projected to the exterior of the thoracic cavity. The other bullet, following a trajectory from back to front, angled left to right and slightly downward in the left hemithorax, led to a tear of

Table 2

Ballistic findings: case description, Porto (1998-2013).

\begin{tabular}{|c|c|c|c|c|c|c|}
\hline & Case 1 & Case 2 & Case 3 & Case 4 & Case 5 & Case 6 \\
\hline \multicolumn{7}{|l|}{ Vehicles } \\
\hline $\begin{array}{l}\text { Distance from which } \\
\text { shot fired }\end{array}$ & $1-2 \mathrm{~m}$ & $10 \mathrm{~m}$ & $15-20 \mathrm{~m}$ & $14 \mathrm{~m}$ & $10-18 \mathrm{~m}$ & $<1 \mathrm{~m}$ \\
\hline Total number of shots & 1 & 6 & 5 & 2 & 3 & 1 \\
\hline $\begin{array}{l}\text { No. of bullet(s) that hit } \\
\text { the victim }\end{array}$ & 1 & 2 & 2 & 1 & 1 & 1 \\
\hline Area of initial impact & $\begin{array}{l}\text { Window of front } \\
\text { door }\end{array}$ & Boot & Boot & Windscreen & Rear bumper & Window of front door \\
\hline Details of bullet(s) hole(s) & None & $\begin{array}{l}\text { - Large loss of paint and } \\
\text { dent on the boot sheet } \\
\text { metal } \\
\text { - Irregular burrs on the } \\
\text { metallic cargo } \\
\text { compartment }\end{array}$ & $\begin{array}{l}\text { 1) Circular loss of } \\
\text { paint around } \\
\text { 2) Irregular loss of } \\
\text { paint around }\end{array}$ & $\begin{array}{l}\text { Radial and } \\
\text { concentric fractures }\end{array}$ & $\begin{array}{l}\text { Dent of the } \\
\text { registration plate }\end{array}$ & None \\
\hline Angle of incidence & Oblique & Perpendicular & Oblique & Oblique & Oblique & Oblique \\
\hline $\begin{array}{l}\text { Trajectory of bullet(s) } \\
\text { that hit the victim }\end{array}$ & $\begin{array}{l}\text { Left to right and } \\
\text { downwards }\end{array}$ & Back to front & $\begin{array}{l}\text { 1) Back to front and } \\
\text { left to right } \\
\text { 2) Back to front and } \\
\text { downwards }\end{array}$ & $\begin{array}{l}\text { Front to back, left to } \\
\text { right and upwards }\end{array}$ & $\begin{array}{l}\text { Back to front, left } \\
\text { to right and upwards }\end{array}$ & $\begin{array}{l}\text { Left to right and } \\
\text { downwards }\end{array}$ \\
\hline
\end{tabular}


Table 3

Pathology findings: case description, Porto (1998-2013).

\begin{tabular}{|c|c|c|c|c|c|c|}
\hline & Case 1 & Case 2 & Case 3 & Case 4 & Case 5 & Case 6 \\
\hline \multicolumn{7}{|l|}{ Victims } \\
\hline No. shots & 1 & 2 & 2 & 1 & 1 & 1 \\
\hline \multicolumn{7}{|l|}{ Entry wound } \\
\hline Anatomical region & $\begin{array}{l}\text { Posterior face of } \\
\text { left hemithorax }\end{array}$ & $\begin{array}{l}\text { Right lumbar } \\
\text { region }\end{array}$ & $\begin{array}{l}\text { 1) Left cervical region } \\
\text { 2) Lateral face of left } \\
\text { hemithorax }\end{array}$ & $\begin{array}{l}\text { Left occipital } \\
\text { region }\end{array}$ & $\begin{array}{l}\text { Posterior face of } \\
\text { left hemithorax }\end{array}$ & $\begin{array}{l}\text { 1) Anterior face of left wrist } \\
\text { 2) Left hemiface of jaw }\end{array}$ \\
\hline Shape & Rounded & Rounded & $\begin{array}{l}\text { 1) Rounded } \\
\text { 2) Elliptical }\end{array}$ & Elliptical & Rounded & Oval \\
\hline Dimensions (mm) & 9 & $\begin{array}{l}\text { 1) } 12 \\
\text { 2) } 15\end{array}$ & $\begin{array}{l}\text { 1) } 10.5 \\
\text { 2) } 11 \times 6\end{array}$ & $12 \times 7$ & 12 & $\begin{array}{l}\text { 1) } 20 \times 15 \\
\text { 2) } 13 \times 8\end{array}$ \\
\hline Other findings & $\begin{array}{l}\text { Visible ecchymosis } \\
\text { around the hole }\end{array}$ & $\begin{array}{l}\text { Slight abrasion } \\
\text { collar }\end{array}$ & $\begin{array}{l}\text { 1) Swelling of the } \\
\text { abrasion collar } \\
\text { 2) Ring of dirt }\end{array}$ & $\begin{array}{l}\text { No radial } \\
\text { fractures }\end{array}$ & No ring of dirt & $\begin{array}{l}\text { 1) Abrasion collar and } \\
\text { no ring of dirt } \\
\text { 2) Wound edges infiltrated } \\
\text { with blood }\end{array}$ \\
\hline \multicolumn{7}{|l|}{ Exit wound } \\
\hline Anatomical region & No exit wound & No exit wound & $\begin{array}{l}\text { 1) Left sternal region } \\
\text { 2) Above the } \\
\text { umbilical scar }\end{array}$ & $\begin{array}{l}\text { No exit } \\
\text { wound }\end{array}$ & No exit wound & $\begin{array}{l}\text { 1) Posterior face of fist } \\
\text { 2) Right side of neck }\end{array}$ \\
\hline Shape & - & - & Elliptical & - & - & $\begin{array}{l}\text { 1) Oval } \\
\text { 2) Irregular }\end{array}$ \\
\hline Dimensions (mm) & - & - & $\begin{array}{l}\text { 1) } 10 \times 7 \\
\text { 2) } 12 \times 6\end{array}$ & - & - & $\begin{array}{l}\text { 1) } 13 \times 17 \\
\text { 2) } 20 \text { (length) }\end{array}$ \\
\hline
\end{tabular}

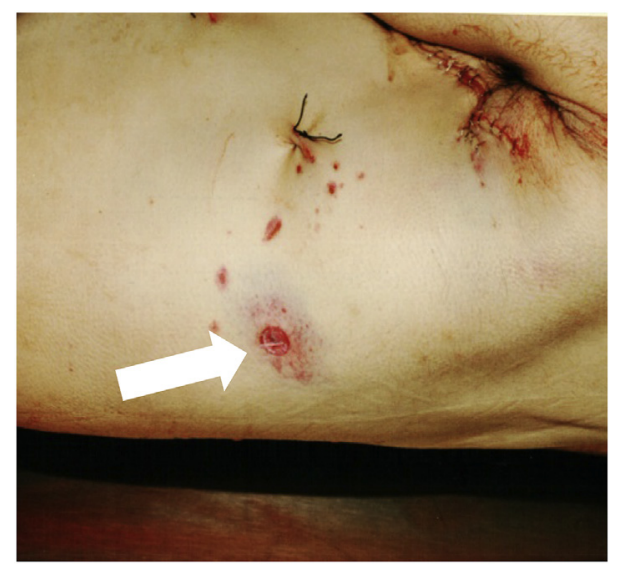

Fig. 2. Case 1: Entry wound on the rear face of the left hemithorax.

elliptical-form with contusion around the edge (Fig. 7), fractured the seventh rib, medium arch, projecting bone splinters into the thoracic cavity and lacerating the parietal pleura. It entered and exited the lower lobe of the left lung. It fractured the articulation between the seventh and eighth left ribs next to the sternum,

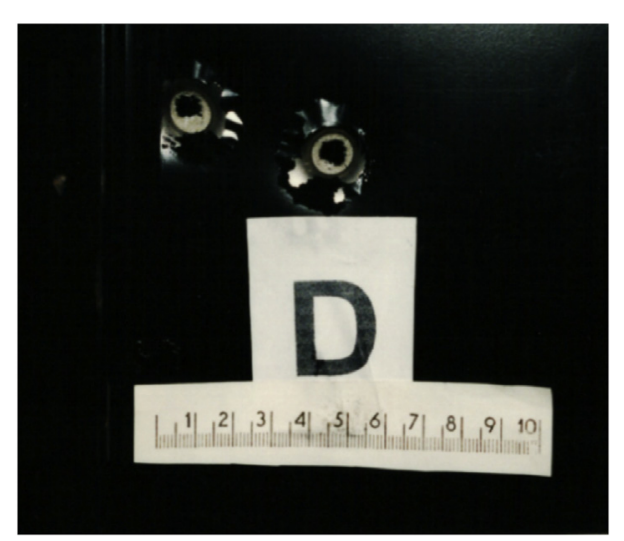

Fig. 3. Case 2: Entry holes of bullets in boot lid.

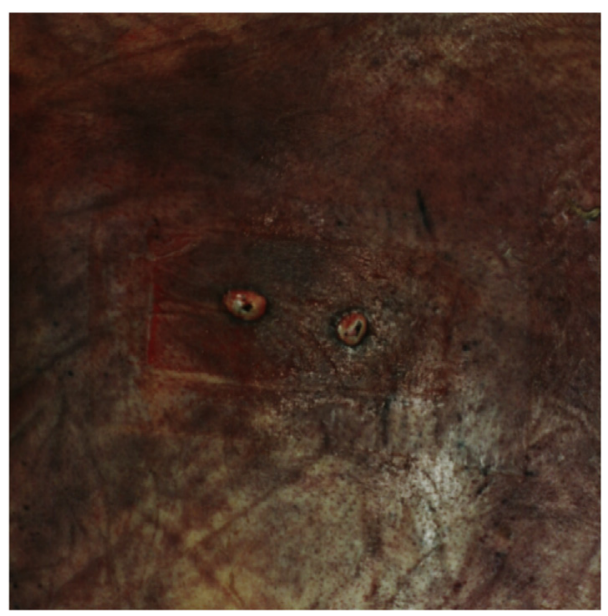

Fig. 4. Case 2: Evidence of different diameters of entry holes in lumbar region, with the same layout as the entry holes in the boot lid (Fig. 3).

projecting cartilaginous splinters outside the chest cavity. The bullet then continued to the abdomen, caused an elliptical shaped tear located $1 \mathrm{~cm}$ above the umbilical scar, with contusion around the edge of the wound, followed by linear tearing toward the right iliac fossa. The bullet then exited the abdomen and hit the right thigh, causing linear abrasion on the antero-internal face of the upper thigh. The victim died immediately after the shooting, as a direct consequence of the listed traumatic thoracic injuries.

\subsubsection{Case 4}

The police officer fired two rounds at the front of the vehicle. One of the bullets ricocheted off the ground and followed an oblique path upwards from left to right before perforating the windscreen and striking the driver of the motor vehicle. The bullet entered the left occipital region of the driver's skull, travelled $15 \mathrm{~cm}$ inside the skull and into the brain causing the laceration of the brain parenchyma, starting at the left occipital lobe, crossing the interhemispherical groove at the midline and ending in the right frontal lobe parenchyma (Fig. 8), where it was collected during the autopsy. Due to the ricochet on the ground, the bullet lost its full 


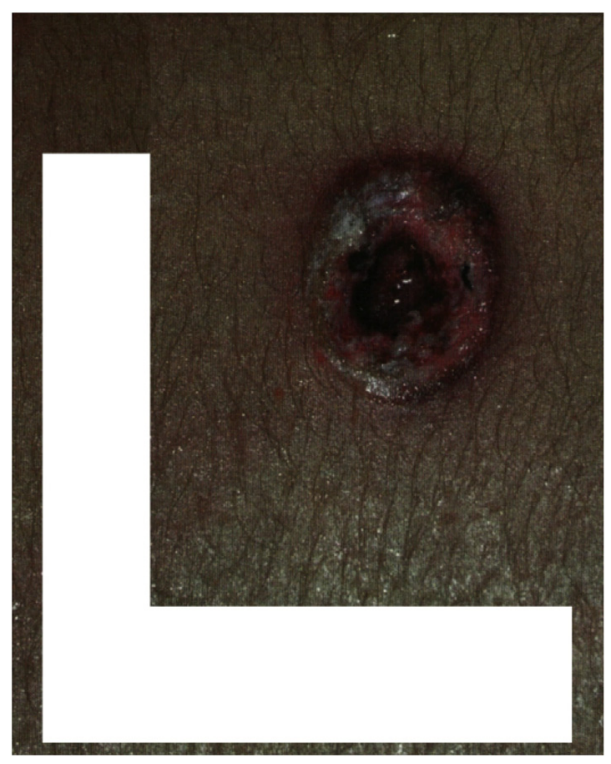

Fig. 5. Case 3: Close up of entry wound on the left side of the 5th dorsal vertebra.

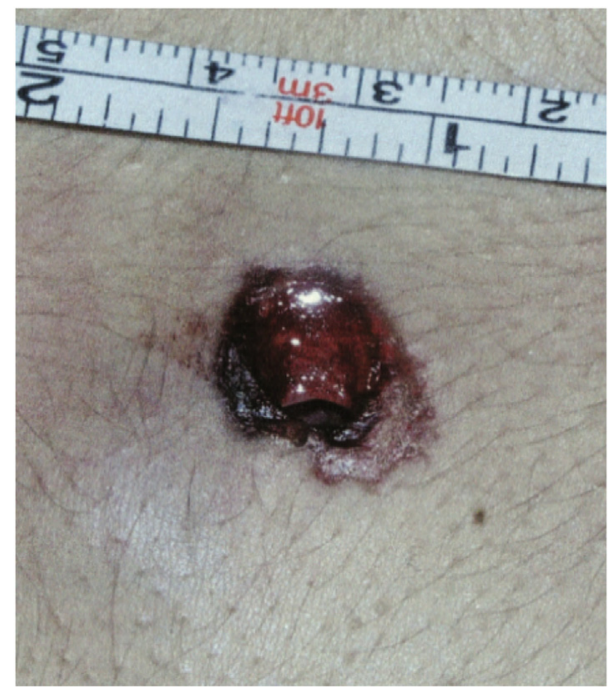

Fig. 6. Case 3: Exit wound close to the articulation of the second left rib with the sternum.

metal jacket and became very deformed, which made an uneven hole in the windscreen of the vehicle and which was far greater than the diameter of the bullet's calibre (Fig. 9), and the same was true for the entry wound on the victim (Fig. 10). The reason why the bullet entered the left occipital area of the head despite the victim sitting facing the police officer, was due to the fact that the victim looked back just before being struck, turning his head to the right side. The victim survived $51 \mathrm{~h}$. Death occurred in a hospital environment as a direct consequence of the traumatic skull injury caused by the bullet.

\subsubsection{Case 5}

The police officer fired and three bullets struck the rear of the motor vehicle. One of the bullets ricocheted off the ground, and its full metal jacket became separated from the core (Fig. 11). It went through the registration plate, went through the boot space, crossed the upholstery of the rear right seat and struck the victim sitting there. The bullet penetrated the rear face of the left

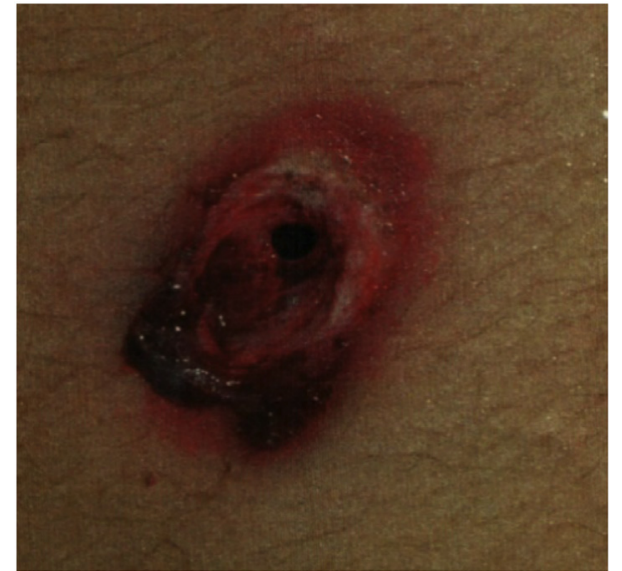

Fig. 7. Case 3: Close up of entry wound with oblique angle of incidence.

hemithorax near the inferior angle of the scapula (Fig. 12). It caused laceration of the intercostal muscles and created two lacerations in the pericardial sac, one on the postero-lateral wall on the left side and the other on the anterior wall. In the heart, the bullet crossed the thickness of the left ventricular wall and caused two lacerations, one on the posterior-lateral wall $(27 \mathrm{~mm})$ and the other on the anterior wall, adjacent to the interventricular septum $(22 \times 10 \mathrm{~mm})$, with a posterior-anterior trajectory and slightly from left to right (Fig. 12). In the left lung the bullet followed a posterioranterior trajectory, causing laceration of the posterior face of the lower lobe and anterior face of the upper lobe. The bullet stopped in the subcutaneous tissue of the anterior face of the left hemithorax, over the seventh intercostal space, $2 \mathrm{~cm}$ from the left edge of the sternum (Fig. 13). The victim died at the scene of the incident, about 6 min after being shot.

\subsubsection{Case 6}

The police officer inadvertently fired a shot when run over by the driver of the motor vehicle. The bullet's path was from left to right and slightly downward. It penetrated the window of the left front door, shattering it. The driver was struck by this bullet in the anterior-inside face of the left wrist. The bullet followed a path from left to right, front to back and downwards, producing an exit hole on the posterior-external face of the fist (Fig. 14). The bullet then entered the driver's face, following a trajectory from front to back, left to right and downwards, causing the comminuted fracture of the left mandibular body close to the angle of the jaw, irregular lacerations on the right half of the platysma muscle and the right sternocleidomastoid muscle and its sheath, and irregular laceration of the right external carotid artery. The exit wound was in the middle-right side of the neck (Fig. 15). The bullet was recovered inside the vehicle, on the carpet next to the rear right seat. The victim died at the scene, as a direct result of the neck and orofacial injuries caused by the passage of the bullet associated with suffocation by massive blood aspiration to the tracheobronchial tree.

\section{Discussion}

The trajectory of the bullets through the motor vehicles and the bodies of the victims was always left to right. This result may be explained by the fact that police officers, when standing, usually approach the occupants of vehicles on the left side, and when in a motor vehicle pursuit, they try to place the police vehicle to the left side of the vehicle being pursued so that the police officer who occupies the front passenger seat may be in a position to shoot out the tyres. 


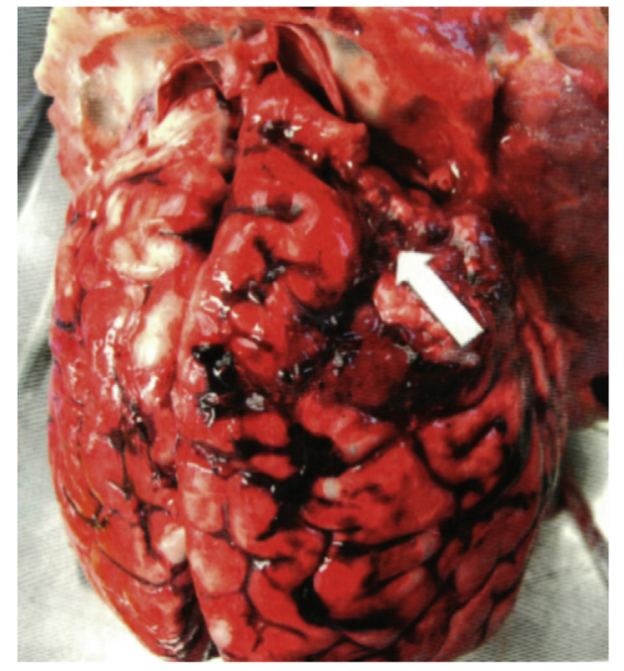

Fig. 8. Case 4: Start of bullet path in left occipital lobe and laceration of cerebral parenchyma.

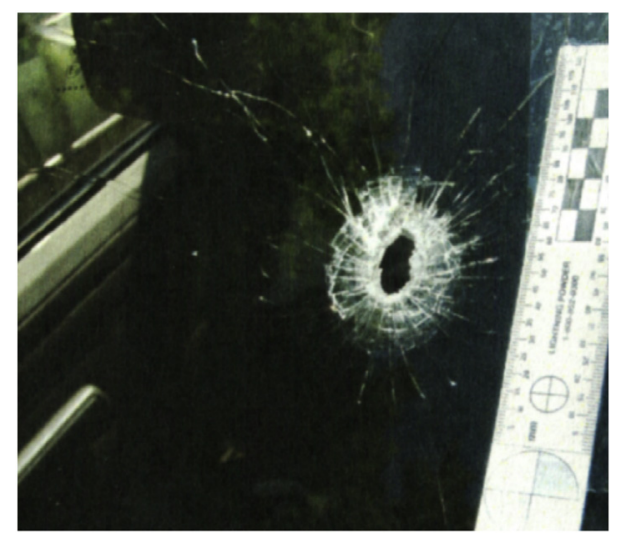

Fig. 9. Case 4: Entry hole of bullet in windscreen of vehicle.

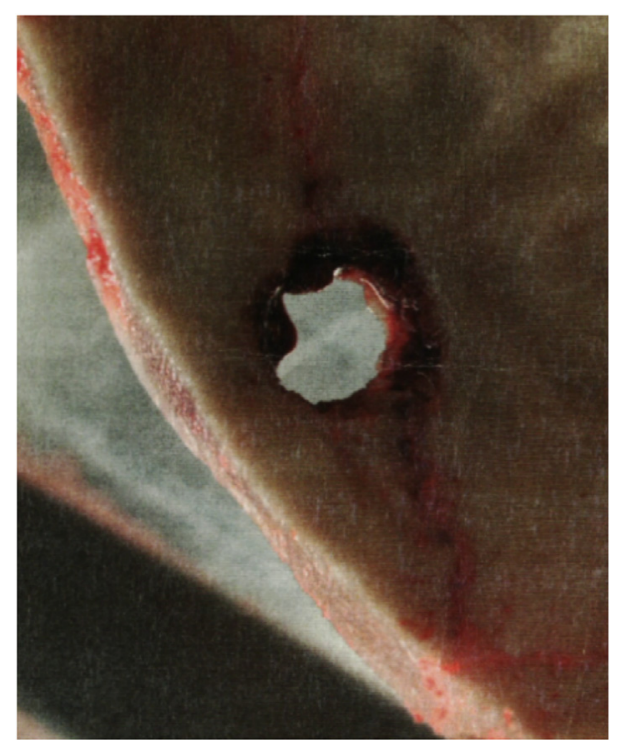

Fig. 10. Case 4: Entry wound in left occipital region with typical internal bevelling.

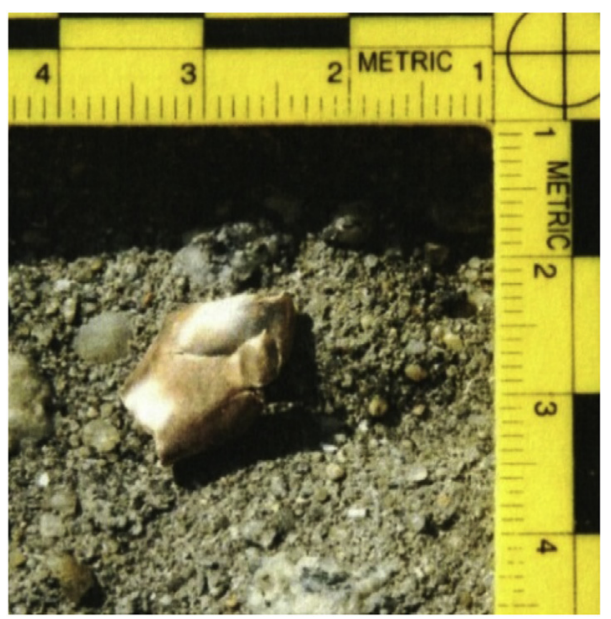

Fig. 11. Case 5: Full metal jacket has separated from the bullet core after ricochet on ground.

Based on the forensic ballistics evidence obtained the bullets that crossed the metal structure and the passenger compartment of vehicles always followed generally linear trajectories until they reached the victims. Case 3 should be highlighted in this regard, not only because the shooting distance was considerable (15 to $20 \mathrm{~m}$ ) but also because the angle of incidence of the two bullets in the vehicle was about $45^{\circ}$. Those two bullets also followed a rectilinear path after hitting the registration plate of the vehicle and then passed through the rear of the seat and the fabric of the back seat before striking the passenger. The bullet paths displayed in this case may have been due to the combination of three factors: the structural weakness of the vehicle, since it was a small city car; the fact that the bullets were fired from a submachine gun, which entailed considerable kinetic energy at the moment of impact; the construction (FMJ) and shape (ogival) of the bullets.

The entry holes into the bodies of the victims are again, with the exception of case 2, always in the left half of the body. The explanation for this seems to be, as for the entry holes in the motor vehicles, the fact that police officers always position themselves on the left side of the vehicle. The dimensions of the entry wounds

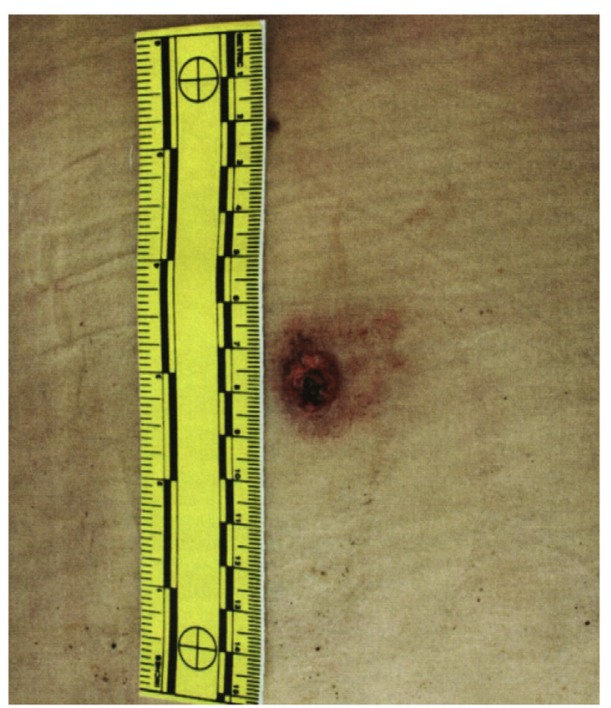

Fig. 12. Case 5: Entry wound on the left hemithorax near the inferior angle of the scapula. 


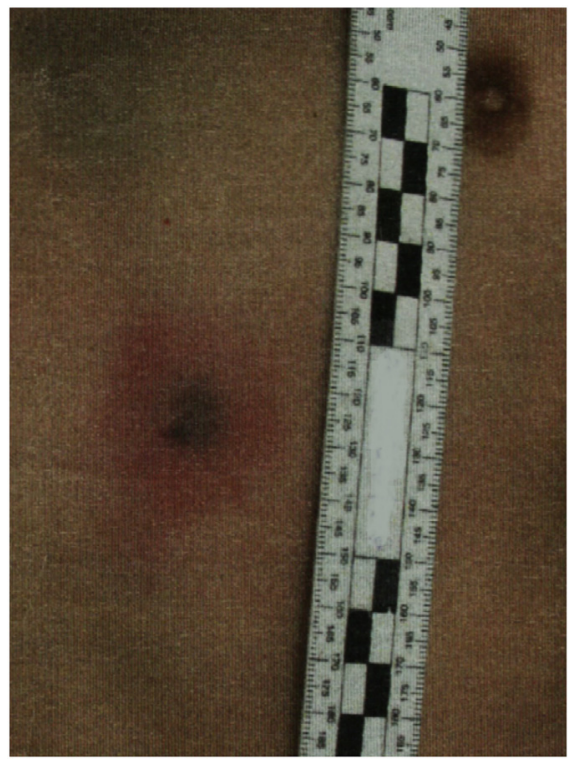

Fig. 13. Case 5: Abrasion in the subcutaneous tissue of anterior face of left hemithorax.

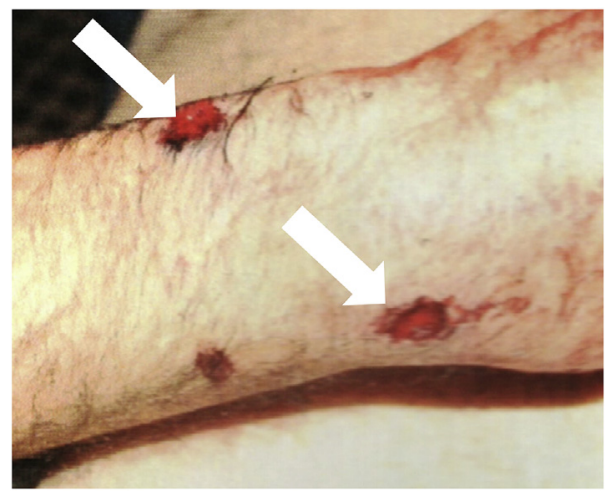

Fig. 14. Case 6: Entry and exit wounds of bullet on left wrist.

were found to always be greater than the calibres of the bullets. This difference may be due to the loss of gyroscopic stability that occurs when the bullets strike and pass through an intermediate barrier, ${ }^{18,19,13}$ the structure of vehicles in this case, as well as the occurrence of their flattening/deformation resulting from the same interaction. $^{13}$

Regarding the removal of bullets from the victims' bodies, this only occurred in cases 3 and 6 . The lack of an exit wound is an expected result when the bullet crosses an intermediate target before hitting the victim. In these cases, the bullet suffers destabilization and/or deformation. ${ }^{20}$ The destabilization will modify the bullet's velocity and direction. ${ }^{21,22}$ The loss of velocity implies less velocity and energy to the next target. The deviation of the normal trajectory offers more contact between the projectile and the target, allowing more transfer of energy. ${ }^{22}$ A destabilized bullet will typically penetrate less than a bullet that strikes the target directly. ${ }^{23}$ A deformed/expanded bullet will present a bigger surface of impact, ${ }^{7}$ which also means a bigger loss of velocity and penetration. In the case 4 of this study, the absence of the exit wound was also predictable because in shots to the skull with low velocity firearms such as handguns not from a close distance it is expected that only an entry wound exists. ${ }^{24}$

In relation to the entry and exit wounds on the victims' bodies, case 6 encompasses the fact that those wounds are not

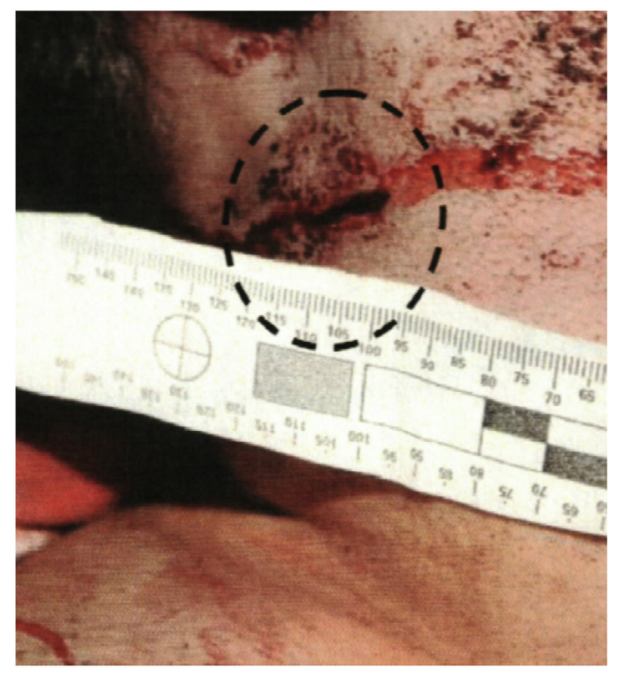

Fig. 15. Case 6: Close up of irregular shape of bullet exit hole in neck.

only on the wrist but also on the face and neck. A reconstruction of the event for court purposes showed that the driver had lifted his left arm just before he was shot in order to protect himself. The bullet travelled through the window of the door and the bone structure of the wrist to enter the face, then into the neck before exiting from the neck. The shot was made from a short distance, and had near maximum kinetic energy at the time it struck the victim. This explains the entry and re-entry wounds and the path followed. On the other hand, the irregularity and large size of the exit hole in the neck may be due to the instability generated in the bullet when it impacted the jaw, as such behaviour is typical of shots by low velocity firearms to this zone of the face. ${ }^{25}$

None of the bullets fragmented or lost relevant mass, despite the deformation that occurred. This result is relatively unexpected. As Vermeij et al. ${ }^{7}$ demonstrated using the $9 \times 19 \mathrm{~mm}$ Luger bullet, the fragmentation of this bullet may happen when it crosses intermediate targets like steel or glass. The non-fragmentation is specially unexpected in the case 5 of this study because the bullets full metal jacket separated from its core before striking the metal structure of the vehicle. About the deformation of the projectile and the loss of their external envelope, it is important to emphasise that this envelope is independent from the internal composition and shape of the bullet.

In relation to the lethality of the bullets in the victims, case 5 showed the victim survived $51 \mathrm{~h}$, notwithstanding the fact that the deformed bullet, after hitting the ground and the windscreen of the vehicle, made a $12 \mathrm{~mm}$ entry wound in the skull and travelled in the brain from the left occipital lobe, crossing the inter-hemispherical groove to the right frontal lobe. It is reasonable to expect that this type of injury would cause immediate or rapid death. ${ }^{20,22}$ However, in this case it did not. Nevertheless, as expected, immediate incapacitation did occur. $^{26,27}$

Case 3 is also to be noted. The victim was quickly disabled, which is expected when the major vessels are hit, ${ }^{12,27}$ the aortic arch in this specific case, and the consequent loss of large volumes of blood within seconds. ${ }^{12}$ Besides, it was proven that the victim's death occurred immediately after he lost consciousness.

In relation to case 6 , the victim continued to drive the vehicle for a few more metres and even exited the vehicle unaided, even after being hit in the carotid artery and having suffered neck injuries. This case permitted the partial confirmation of the 
results obtained by Kunz et al. $^{8}$ in the study of shots fired through the window of a vehicle. In that case study as in case 6 herein, the $9 \times 19 \mathrm{~mm}$ bullet fired did not exhibit sufficient stopping power after negotiating intermediate barriers, namely it travelled through the window of the vehicle, entered and exited the wrist, entered the face and exited at the victim's neck before continuing its path inside the vehicle. The victim still managed to perform the movements referred to. This type of full metal jacket bullet does not guarantee the absence of collateral damage to third party occupants of vehicles because even after striking the driver, it continued its path within the interior of the vehicle and came to rest in the rear seat. However, in the present case, as in others, the occurrence of any damage to third parties was not checked.

The main limitation of this study is the small number of metropolitan cases available in which lethal injuries were sustained when police fired at motor vehicles in order to stop them. However, such incidents have generated social alarm and grave concern among formal entities who seek greater control of the police response to such incidents in Portugal. ${ }^{3,9}$ They have also resulted in a high rate of judicial condemnation of police officers. Case studies 4 and 6 are examples. One should note that the information on the total number of police shootings against motor vehicles between 1998 and 2013 is not available because in Portugal only the fatal cases have been registered. Moreover, this study is of added value as it comprises an uncommon examination of actual police cases that relates various aspects of forensic ballistics and connects elements of the examination of crime scenes with autopsy findings. The authorisation obtained to collect and publish actual images contained in the forensic pathology and forensic ballistics reports used in the criminal proceedings is a special privilege contributing to knowledge in the field of forensic sciences. There is no need to use x-rays to complete the information on the autopsy, thus it was only used the information provided from the autopsy.

Although not the procedure adopted in other countries, the full metal jacket type is the type of cartridges distributed in Portugal to the police officers. In Portugal there is a low investment in this research area and a usual delay in the introduction of innovative technical means-tested in other. Also, the general idea that police service cartridges such as QD PEP may cause greater tissue destruction at the inlet and therefore results in wounds that are particularly alarming when shown to the public might be another reason for not using this cartridges.

The cases studied show that shooting at motor vehicles with full metal jacket bullets, with the sole intention of immobilising those vehicles, entails real danger to the lives of the occupants. Therefore, it should be avoided unless required to protect life or prevent serious injury to police officers or third party persons. In this regard, governments and police agencies should establish policies and standard operating procedures governing such shootings. Nevertheless, there may be situations where shooting at a vehicle is necessary in order to immobilize it. For this reason, research should focus on developing specialized ammunition designed to minimize the risk to innocent third parties and safeguard the lives of suspects within the vehicle, as it happens for instance with soft point or hollow point ammunition (e.g., QD PEP). Portuguese authorities should adopt this kind of ammunition. Research should also be undertaken to pursue the creation of less-lethal means for the forced immobilisation of vehicles. In addition, police officers should receive training specifically intended for operations that may involve shooting at vehicles.

\section{Acknowledgements}

We would like to thank Professor Teresa Magalhães, Director of the Department of Legal Medicine and Forensic Sciences of the Faculty of Medicine of the University of Porto, for her help in our request for authorisation to consult the criminal proceedings in the courts. Silvia Fraga is the recipient of a Post Doc grant from Fundação para a Ciência e a Tecnologia (SFRH/BPD/ 97015/2013).

\section{Conflict of interest}

The authors hereby declare that they had no financial support or other conflicts of interest regarding the publication of this article.

\section{Funding}

None.

\section{Ethical approval}

Not required.

\section{References}

1. O'Loan N. The use of firearms by police officers in Northern Ireland. In: Inspectorate General of Home Affairs, editor. The use of firearms by police officers. Lisbon: Inspectorate General of Home Affairs; 2004. p. 165-75.

2. Diaz C. The use of firearms by police officers in France. In: Inspectorate General of Home Affairs, editor. The use of firearms by police officers. Lisbon: Inspectorate General of Home Affairs; 2004. p. 177-85.

3. Nogueira MJRL. The use of firearms by police officers - some aspects. In: Inspectorate General of Home Affairs, editor. The use of firearms by police officers. Lisbon: Inspectorate General of Home Affairs; 2004. p. 211-26.

4. Olse FZ. The use of police firearms in Denmark. Copenhagen: National Commissioner of Police; 2008.

5. Fachner G, Carter S. An assessment of deadly force in the Philadelphia police department. Colaborative Reform Initiative. Washington, DC: Office of Community Oriented Policing Services; 2015.

6. Coupland R. Clinical and legal significance of fragmentation of bullets in relation to size of wounds. Br Med J 1999;319:403-6.

7. Vermeij E, Rijnders M, Pieper P, Hermsen R. Interaction with intermediate targets: materials transfer and damage. Forensic Sci Int 2012;223: $125-35$.

8. Kunz SN, Zinka BM, Fieseler S, Graw M, Peschel O. Laminated safety glass as an intermediate target: a wound ballistic study. J Forensic Sci 2012;57: $1241-6$.

9. Almeida JMR. Some topics on the use of firearms by police officers. In: Inspectorate General of Home Affairs, editor. The use of firearms by police officers. Lisbon: Inspectorate General of Home Affairs; 2004. p. 227-34.

10. Warlow TA. Firearms, the law and forensic ballistics. 3rd ed. London: CRC Press; 2011.

11. Jussila J, Kjellström BT, Leppäniemi A. Ballistic variables and tissue devitalisation in penetrating injury - establishing relationship through meta-analysis of a number of pig tests. Injury 2005;36:282-92.

12. Maiden N. Ballistics reviews: mechanisms of bullet wound trauma. Forensic Sci Med Pathol 2009;5:204-9.

13. Matoso RI, Freire AR, Santos LSM, Junior ED, Rossi AC, Prado FB. Comparison of gunshot entrance morphologies caused by .40-Caliber Smith\&Wesson, .380Caliber, and 9-mm luger bullets: a finite element analysis study. Plos One 2014;9:1-8.

14. Santucci RA, Chang Y-J. Ballistics for physicians: myths about wound ballistics and gunshot injuries. J Urol 2004;171:1408-14.

15. Hanna TN, Shuaib W, Han T, Mehta A, Khosa F. Firearms, bullets, and wound ballistics: an imaging primer. Injury 2015;46:1186-96.

16. Nennstiel R. Prediction of the remaining velocity of some handgun perforating thin metal sheets. Forensic Sci Int 1999;102:121-32.

17. Bresson F, Ducouret J, Peyré J, Maréchal C, Delille R, Colard T, et al. Experimental study of the expansion dynamic of $9 \mathrm{~mm}$ parabellum hollow point projectiles in ballistic gelatin. Forensic Sci Int 2012;219:113-8.

18. DiMaio VJM. Gunshot wounds: practical aspects of firearms, ballistics, and forensic techniques. 2nd ed. Boca Raton: CRC Press; 1999.

19. Farrugia A, Raul JS, Geraut A, Tortel MC, Ludes B. Destabilization and intracranial fragmentation of a full metal jacket bullet. J Forensic Leg Med 2009;16: 400-2.

20. DiMaio VJM, Dana SE. Handbook of forensic pathology. 2nd ed. Boca Raton: Taylor \& Francis; 2006. 
21. Kneubuehl BP. Basics. In: Kneubuehl BP, editor. Wound ballistics: basics and applications. Translation of the revised third German edition (2008). Berlin: Springer; 2011. p. 3-85.

22. Saukko P, Knight B. Knight's forensic pathology. 3rd ed. London: Arnold; 2004.

23. Haag LC. Wound production by ricocheted and destabilized bullets. Am J Foren Med Path 2007;28:4-12.

24. Betz P, Stiefel D, Eisenmenger W. Cranial fractures and direction of fire in low velocity gunshots. Int J Leg Med 1996;109:58-61.
25. Giannou C, Baldan M, Molde A. Maxillo-facial injuries. In: War surgery: working with limited resources in armed conflict and other situations of violence, vol. 2. Geneva: International Committee of the Red Cross; 2013. p. 283-307.

26. Newgard K. The physiological effects of handgun bullets: the mecanisms of wounding and incapacitation. Wound Ballist Rev 1992;1:12-7.

27. Karger B. Penetrating gunshots to the head and lack of immediate incapacitation I. Wound ballistics and mechanisms of incapacitation. Int J Leg Med 1995;108:53-61. 